\title{
CONCERNING THE SELECTION OF DESIGN AND TECHNOLOGY SOLUTION FOR A MINI-HOTEL CONSTRUCTION
}

\author{
Dmytriieva N.V., Ph.D., associate professor, \\ Odessa State Academy of Civil Engineering and Architecture \\ dmitrieva.nv76@gmail.com ORCID ID: 0000-0002-4828-1644 \\ Agafonova I.P., senior lecturer, \\ Bendery branch of PSU named after T.G. Shevchenko \\ barkaririna@bk.ru ORCID ID: 0000-0003-4330-2642 \\ Tugolukov Yu.S., magistrand \\ Bendery branch of PSU named after T.G. Shevchenko \\ zvezdastolicy@gmail.com ORCID ID: 0000-0002-3679-5955
}

\begin{abstract}
Annotation. The article considers the features and advantages of innovative design and technology solution for mini-hotels construction in the framework of eco-tourism development. The examination of the main potentials of eco-tourism development in Ukraine and Moldova, are presented on the example of the city of Tiraspol. Space planning and design features of the project "Dubovaya Roshcha" tourist complex in Tiraspol, Moldova are characterized there. This article presents a method of multicriteria analysis of design and technology solutions based on the factor evaluation of decision options of low-rise building construction. In this examination the main factors influencing the choice of building structures were emphasized.
\end{abstract}

Key words: metal structures, Light steel thin-walled structures, wooden structures, CLTpanels, SIP-panels, evaluation criteria, eco-construction.

Introduction. Today tourism is defined as a "phenomenon of the XXI century", which has become one of the leading areas of socio-economic activity. The travel business can justly be considered a business of the XXI century, as it is one of the most dynamic and profitable among all sectors of the world economy. The global nature of tourism and priority in the world economy is evidenced by quite a considerable tourist revenue, making $8 \%$ of the world exports and $30 \%$ of the international trade in services, and the annual growth of world tourist flows by $4-5 \%$ [1]. Hotel construction is an integral part of the travel business.

Now, tourist activity is in the stage of reforming and development in Ukraine. Available tourism resources are used not in full.

Most European travel companies operate inbound, outbound and domestic tourism (in order of directions priority). In Ukraine, 90\% of travel companies are focused on outbound tourism [2] since 2015. The reasons for such preferences of travel companies is poorly developed tourism infrastructure. Therefore, the development of tourist complexes construction in the CIS countries, in particular in Ukraine and Moldova, has become one of the most important social and economic tasks at the turn of the 21 st century.

Analysis of recent research and publications. At the beginning of the 21 st century, there was a growing demand for more comfortable tourism, and now super-comfortable hotels, high-class hotels are being designed and built. For example, an absolutely amazing resort El Gouna was built in Egypt, representing a fairy city on the shore of the Red Sea and looking like Venice. This city consists of comfortable mini-hotel cottages located along canals and bays, replacing streets and sites [3]. But in regions with unstable economies, the construction of large hotels is not advisable, since the payback period is more than 10 years.

In developed countries, the vast majority of tourism services are sold to the locals. For example, in German hotels - $88 \%$ of visitors are the Germans and $12 \%$ are the foreigners, in Finland, respectively $-73 \%$ and $27 \%$, in France $-71 \%$ and $29 \%$, in Holland $-68 \%$ and $32 \%$, in the US hotels - $85 \%$ of guests are the Americans themselves [4]. 
And in connection with the aggravated epidemiological and economic situation in the world in 2020, the development of domestic tourism is currently topical, as well as mini-hotels construction.

Ukraine and Moldova with their huge natural resources, unique landscape and climatic conditions and favorable geographical location have extremely favorable conditions for the development of ecological tourism and rural green tourism. According to the tourism development plan approved by the Cabinet of Ministers of Ukraine, the target program "Mandrui Ukrainoiu" and "Program Tourism-2030" developed by the government of Moldova, with a support of the US International Development Agency, together with the government of Sweden and Great Britain, the work for improving rural, ethnographic, ecological, sports and business tourism should be contemplated. It is planned to carry out works in the field of wine, medical, children's and youth tourism. In this regard, the development of constructive and technological as well as improvement of architectural and planning solutions of hotel complexes for each type of tourism is currently topical.

In developed countries, the vast majority of tourism services are sold to local citizens. For example, in hotels in Germany the attendance by Germans is $88 \%$, and by foreigners $12 \%$, in Finland, respectively $-73 \%$ and $27 \%$, in France $-71 \%$ and $29 \%$, in Holland $-68 \%$ and $32 \%$, in the USA - 85\% of staying in hotels are the Americans themselves [4].

Modern developers have been introducing environmental technologies for several decades during the construction of residential and hotel buildings, industrial and public facilities. The main ones are:

- reduction of rubbish and waste during construction;

- use of environmentally safe building materials;

- using of energy efficient technologies;

- creation of an optimal microclimate;

- design of resource-saving engineering systems.

At present, special attention in world practice is paid to usage of structures made of natural materials: wood, stone, textiles, sand. When decorating facades and interiors, safe paints without toxic substances are used. The usage of heat-insulating materials and energy-efficient double-glazed windows makes it possible to increase the heat and acoustic isolation of buildings.

The emergence of new innovative technologies in construction, together with the development of metallurgy and woodworking industries, make metal and wood one of the most promising materials of the future.

The works of such scientists as: Vatin N.I., Sinelnikov A.S., Zinkevich O.G. are devoted to the solution of theoretical, technical and practical problems in the design and construction of buildings from the light steel thin-walled structures profile and "frameless" structures and methods of rational design of frames from light steel thin-walled structures.

The works of such authors as L.A. Devyatnikova, A.A. Simonov, V.M. Popov, S.I. Roshchina, B.V. Labudin are devoted to the design and construction of timber buildings.

Formulation of the problem. The widespread use of thin-walled structures in Ukraine is cumbered largely due to the imperfection of domestic regulatory and methodological bases for the light steel thin-walled structures calculation, the lack of proper instructions for installation and operation, and sufficient experience in the design of such structures. The main effective document regulating the use, design of structures from steel thin-walled profiles on the territory of Ukraine is DSTU-N B V.2.6-87: 2009 "Design of structures using steel thin-walled profiles". Despite the obvious advantages in using Light steel thin-walled structures profiles [5], there are also a number of operational disadvantages. The main disadvantage is the violation of the comfortable microclimate in the premises, which occurs due to the presence of numerous heat-conducting inclusions in the outer shells, the so-called "cold bridges". The formation of moisture is observed in the locations of the profiles, leading to the appearance of mold fungi. To a large extent, heat-conducting inclusions during the heating season lead to external heat losses, which directly affect the public utility services payment during the heating season [6].

As for the proportion of wooden houses in the structure of individual and cottage housing, according to various estimates, it makes from 5 to $20 \%$. In retrospect of the last five years, positive 
dynamics can be observed. The Ukrainian market of wooden housing construction is promising, since today the ratio of products sold can be estimated as 70\% - domestic and 30\% - foreign.

In relation to the geography of demand, the regional specificity of the consumption of wooden houses is certainly evident. The most active are Kiev and Kiev region, $80 \%$ of all projects being implemented are concentrated there. Also traditionally active are the Carpathians, Zakarpatska Oblast, where the greatest demand for rounded wood is concentrated. In Donetsk, Kharkov and Dnepropetrovsk regions, glued laminated timber is gaining more and more popularity. Also, there was a demand for wooden houses of all types on the South Coast of the Crimea, in Odessa region [7].

At the same time, wooden walls made of simple timber or logs do not meet modern requirements for heat insulation, which causes large heat losses during operation and, accordingly, high heating costs.

Planning solutions based on small spans, which is provided by a simple wooden beam also do not meet comfort requirements. Expansion of premises (based on increasing the spans), ensuring energy efficiency of the enclosing structures and fire safety of the whole house are today the most important problems in design and building of low-rise wooden house construction.

The combination of the above-mentioned factors ensures the minimum energy consumption of the building, while the key factors increasing the energy-efficiency of shells in buildings and structures are thermal resistance growth of its structural elements and reduction in numbers of heat bridges. The solution of these problems is now more urgent than ever and requires the elaboration of measures to solve it.

Evaluating the possibility of using one or another constructive and technological solution, customers are generally inherent in some conservatism and even inertness in the choice of technologies and materials. Therefore, the argumentation of technical and economic indicators of solutions based on multi-criteria analysis method [8], will determine the most rational option for a mini-hotel construction. For this purpose, using the example of designing a mini-hotel "Dubovaya Roshcha", a method of factor evaluation in selection of a rational constructive and technological solution has been developed.

The purpose of this article is to consider the selection of constructive and technological solution for the mini-hotels construction by reasoning based on the factor evaluation.

Materials and research methods. Considering the development applicability of producing molded sections from galvanized steel and wooden structures in Ukraine and Moldova over the past decade.

Light steel thin-walled structures and wooden structures have become an alternative to the use of structures such as reinforced concrete, brick, sawn shell, aerated concrete or rolled steel due to the significant economic effect in the above construction area due to the reduction of deadweight and seismic loads, reduction of transport costs and installation costs, reduction terms of construction without the use of construction machines.

The selection criteria have a multilevel approach, which involves solving numerous problems: technical, technological, operational, economic and environmental.

The following criteria (determining the manufacturability of work) were selected in the studies - the labor intensity and installation speed of the material with the least amount of waste, the convenience of material cutting, transportability, installation without need of special equipment and highly qualified workers, etc. A set of criteria such as moisture resistance, sound insulation, biological and chemical inertness, fire resistance, maintainability, durability, environmental safety and cost were also taken into account when making a selection.

The factor evaluation methodology included the selection of the most appropriate wall construction material using qualitative and quantitative criteria.

The quality criteria include: a possibility of all-season installation; environmental safety; fire safety.

Quantitative criteria include: construction cost; minimum wall thickness (excluding insulation); frost resistance; sound insulation; construction period; lifetime; coefficient of heat conductivity. 
An individual communicative method was used in selecting alternatives and determining the assessment of the criteria - when a single expert generates variant solutions. After that, an expertspecialist determined the validity ratio of a particular factor by quantitative evaluation of each criterion.

Monitoring the market of construction technologies, which are the most in demand on the territory of Ukraine, Moldova and the CIS for mini-hotels construction, the following main materials were preferred: ceramic bricks, wooden bricks, rounded logs, profiled and glued beams, a wooden frame made of SIP panels, Light steel thin-walled structures.

Construction is planned on the riverbanks of Dniester in Tiraspol, on a designated area of 0.7 hectares. The project concept provides the construction of a mini-hotel consisting of 7 individual "guest houses", with a space-planning solution of two types: Type 1 - dimensions on grid: 1-3 (10.45 $\mathrm{m})$ and A-B $(11.76 \mathrm{~m})$ and floor height of $3.0 \mathrm{~m}$ (fig. 2); Type 2 - dimensions on grid: 1-2 (6.35 m) and A-B $(6.6 \mathrm{~m})$ and floor height of $2.9 \mathrm{~m}$, a restaurant with dimensions on grid 14.9x21.09, adult and children's pools, gazebos, a bath complex and parking for 8 places, presented on the general layout (Pic. 1-4).

The concept of the mini-hotel is based on a combination of features of the natural landscape and architectural solutions that are non-standard for a suburban project. The modern architecture is complemented by panoramic glazing, adopted from high-tech high-rise construction practice. This will create spacious, deep interior zones without compromising the residents' comfort (width-depth ratio of premises is $2.00-1.63$ ).
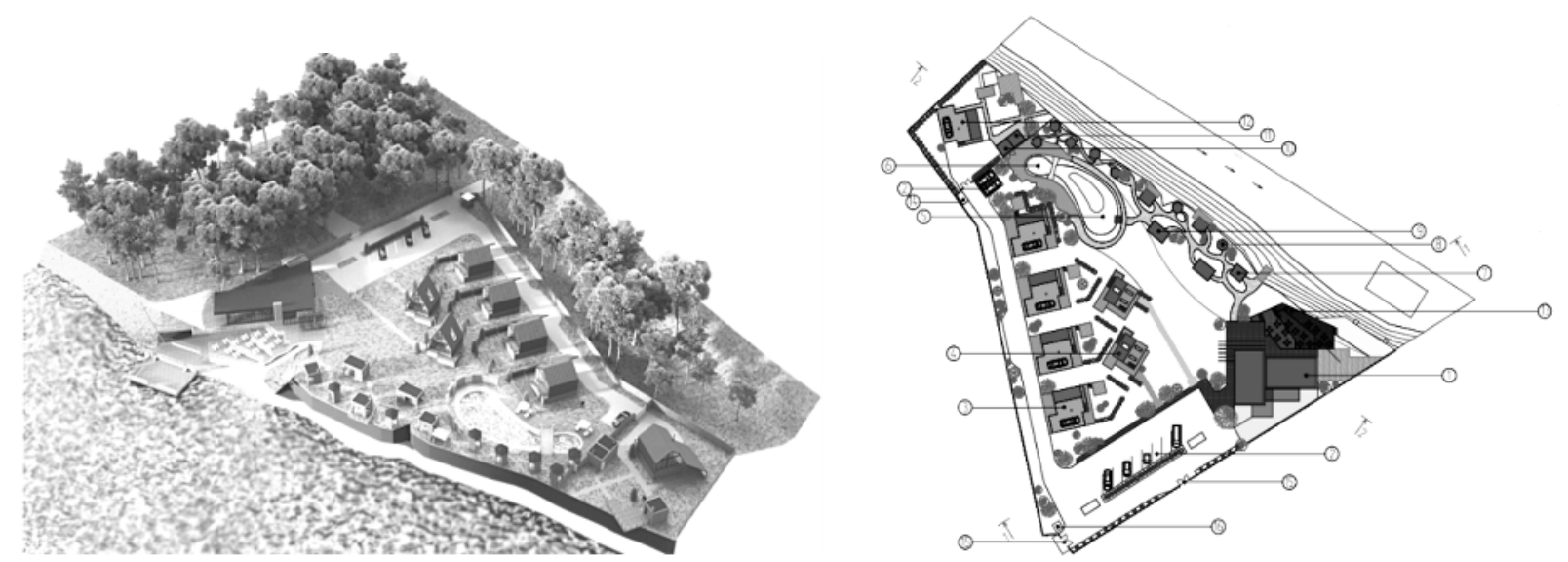

Fig. 1 General layout

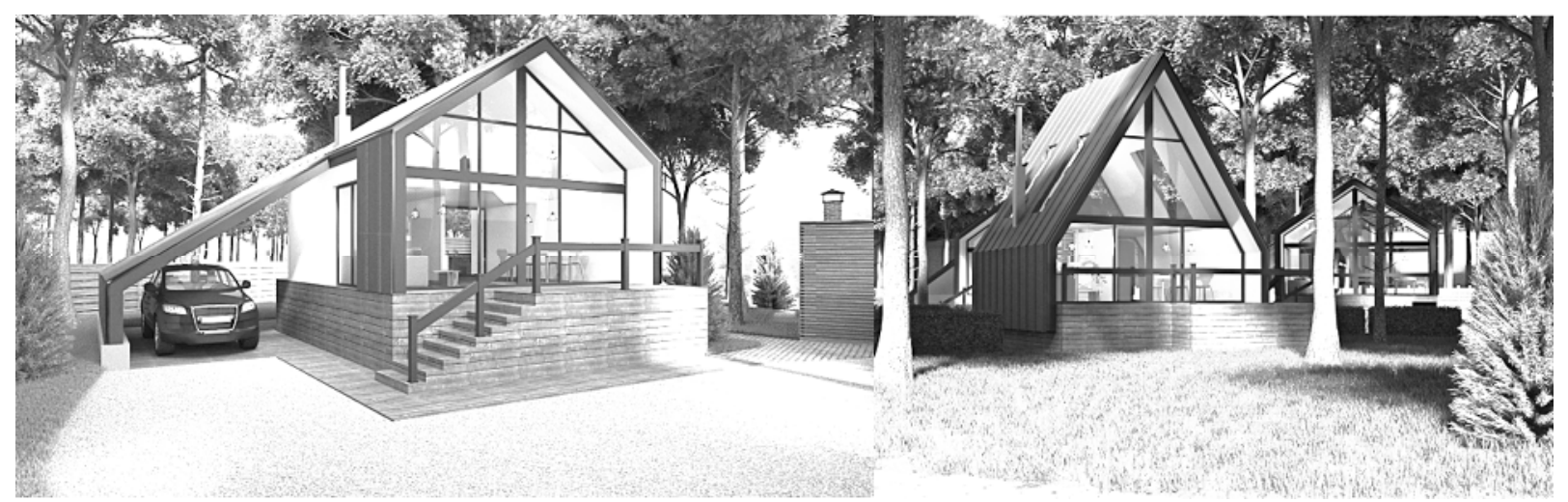

Fig. 2 Visualization of hotel houses projects Type 1 and Type 2 
1 floor plan
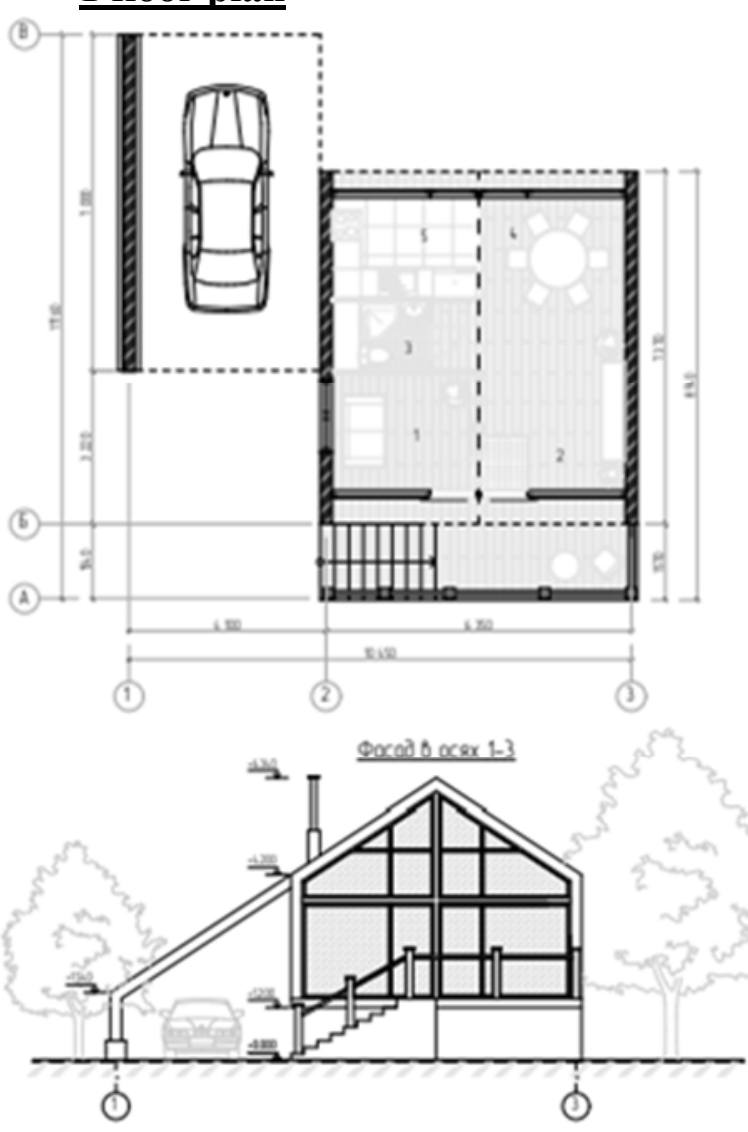

Elevation on grid 1-3

House 1

Fig. 3. Space-planning solution of a hotel house Type 1: Plans of the 1st and 2nd floors and facades $1-3$ and 3-1
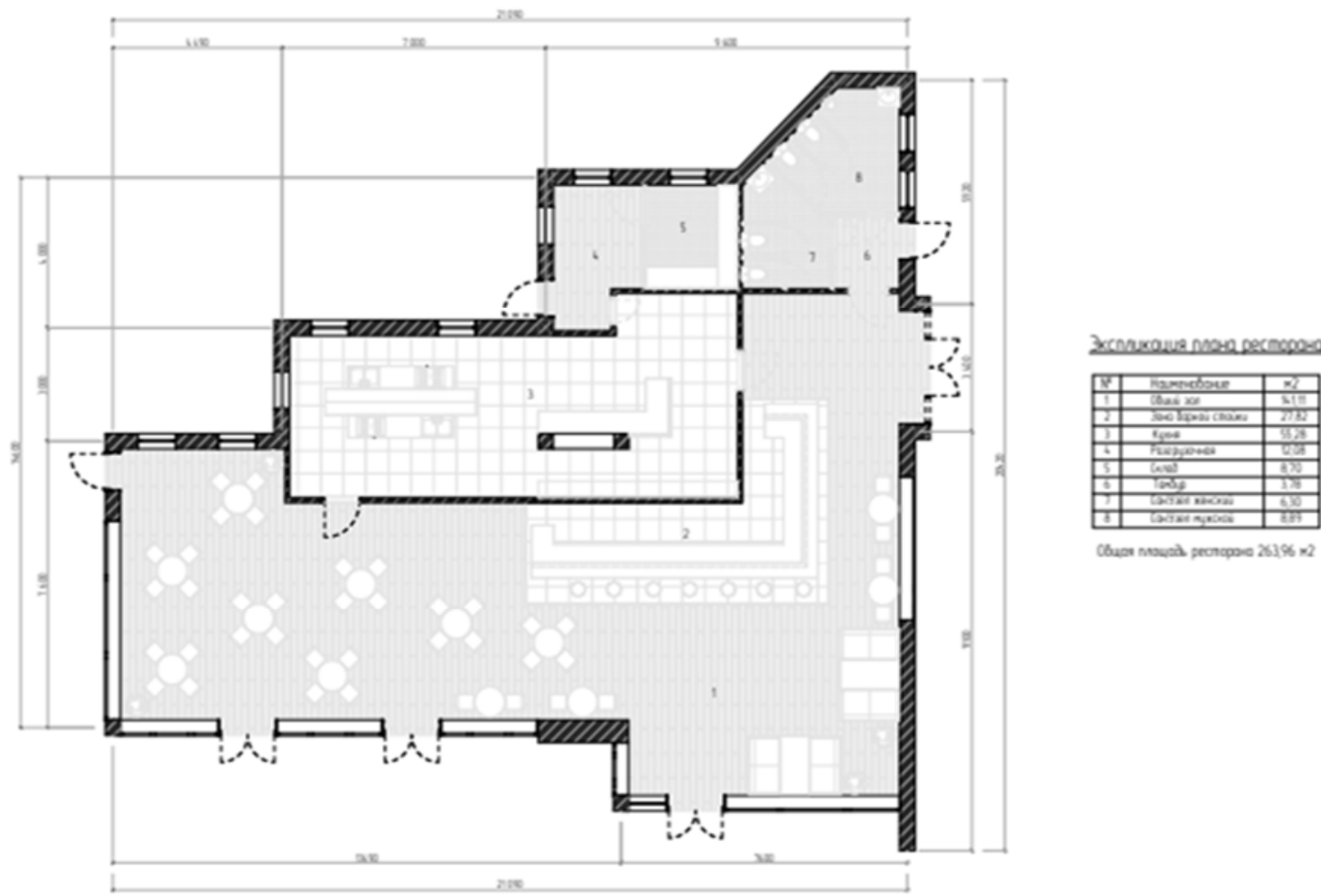

Fig. 4. Restaurant plan 
Structural solutions of load-bearing external and internal walls are taken with a thickness of $200 \mathrm{~mm}$, partitions $-100 \mathrm{~mm}$ with panel heat-sound isolating material - AcousticWool Sonet P.

The rafter system was adopted as the load-bearing element of the roof. The roof covering is made of Ruukki RAN-20B corrugated board. The angle of roof inclination is $25^{\circ}$ and $50^{\circ}$.

For a preliminary analysis, based on the expert estimation of available technical information, a table was compiled for comparing materials for the construction of the frame of "hotel" houses according to the selected criteria (table 1).

The first stage of the analysis is ranking according to the importance degree of wall construction materials, based on the information presented in the Table 1. Criteria 1 and 2 are not significant when choosing materials, because the $1^{\text {st }}$ criterion becomes the same for all materials when using additional measures (antifreeze additives), and the $2^{\text {nd }}$ one is the same for all options, therefore, they may not be taken into consideration in the construction of analytical diagrams. The third and fifth criteria were converted from qualitative indicators into quantitative ones, by assigning them points from 1 to 5 .

The quantitative evaluation of indicators was carried out by means of expert method based on the available technical and reference documentation analysis [9-15].

All criteria are reduced to a single point system, depending on the weight coefficient, adopted from 0.1 to 1 . Evaluation of structural and technological solutions by quantitative criteria is carried out on a five-point scale, where 1 and 5 points are assigned to the minimum and maximum values, respectively. The rest of points were calculated by means of interpolation and are presented in the Table 1.

Thus, according to the criteria evaluation data, the highest number of points was taken by the building technology of CLT-panel -42.2 points, the least number - the building technology of the rounded timber - 28.15 points.

Analysis of the criteria made it possible to single out constructive and technological solutions of rounded timber and ceramic bricks. Both materials have the greatest strength, labor intensity and walls construction period of a "hotel" house of Type 1. At the same time, these two solutions have the lowest resistance to heat loss among all, which is a key criterion for energy efficiency.

Table 1

Multi-criteria evaluation of constructive and technological solutions

\begin{tabular}{|c|c|c|c|c|c|c|c|c|}
\hline \multirow[b]{2}{*}{$\begin{array}{l}\text { Decision } \\
\text { Criteria }\end{array}$} & \multicolumn{8}{|c|}{ Name of design and technology solution of building frame assembly } \\
\hline & 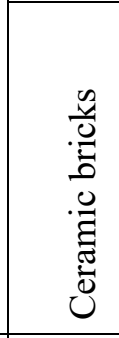 & 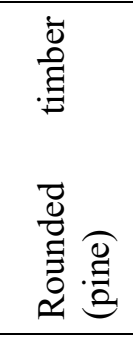 & $\begin{array}{l}\frac{y}{0} \\
\frac{0}{0} \\
\overline{0} \\
0 \\
0 \\
3\end{array}$ & 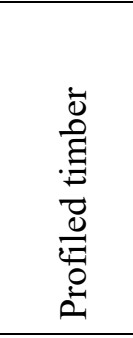 & 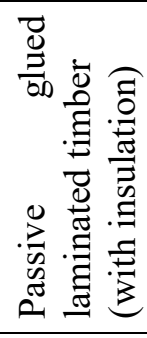 & 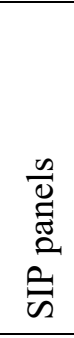 & 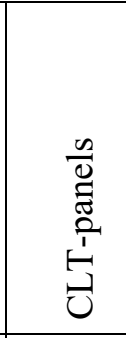 & 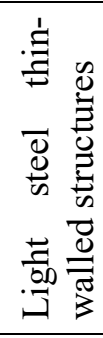 \\
\hline 1 & 2 & 3 & 4 & 5 & 6 & 7 & 8 & 9 \\
\hline $\begin{array}{l}\text { Possibility of all-season } \\
\text { installation }\end{array}$ & no & yes & yes & yes & yes & yes & yes & yes \\
\hline Number of points, $K=0,3$ & 0,6 & 1,5 & 1,5 & 1,5 & 1,5 & 1,5 & 1,5 & 1,5 \\
\hline Ecological safety & yes & yes & yes & yes & yes & yes & yes & yes \\
\hline Number of points, $K=1$ & 5 & 5 & 5 & 5 & 5 & 5 & 5 & 5 \\
\hline 1 & 2 & 3 & 4 & 5 & 6 & 7 & 8 & 9 \\
\hline Fire safety & high & low & low & low & middle & low & middle & high \\
\hline Number of points, $K=0,9$ & 4,5 & 0,9 & 0,9 & 0,9 & 2,7 & 0,9 & 2,7 & 4,5 \\
\hline Dampness, $\%$ & 0,5 & $12-18$ & $8-10$ & $12-20$ & $9-10$ & 12 & 12 & 0 \\
\hline
\end{tabular}




\begin{tabular}{|c|c|c|c|c|c|c|c|c|}
\hline Number of points, $K=0,6$ & 3 & 0,9 & 2,4 & 0,6 & 2,4 & 1,8 & 1,8 & 3 \\
\hline Bio-exposure & no & $\begin{array}{l}\text { exposed } \\
\text { to }\end{array}$ & no & $\begin{array}{c}\text { less } \\
\text { exposed } \\
\text { to }\end{array}$ & $\begin{array}{l}\text { less } \\
\text { exposed } \\
\text { to }\end{array}$ & no & no & no \\
\hline Number of points, $K=0,5$ & 0,5 & 0,5 & 2,5 & 1,5 & 1,5 & 2,5 & 2,5 & 2,5 \\
\hline $\begin{array}{l}\text { Coefficient of heat } \\
\text { conductivity, } \mathrm{W} /\left(\mathrm{m}^{*} \mathrm{C}^{\circ}\right)\end{array}$ & 0,47 & 0,23 & 0,18 & 0,18 & 0,1 & 0,04 & $\begin{array}{c}0,085- \\
0,13\end{array}$ & 0,045 \\
\hline Number of points, $K=1$ & 1 & 2,5 & 3 & 3 & 4 & 5 & 4 & 4,5 \\
\hline Lifetime, years & 80 & 100 & 100 & 100 & 100 & До 60 & over 50 & 50 \\
\hline Number of points, $K=0,8$ & 3,2 & 4 & 4 & 4 & 4 & 2,4 & 1,6 & 1,6 \\
\hline $\begin{array}{l}\text { Labour Effort of } \\
\text { construction project } \\
\text { Type 1, resource days }\end{array}$ & 65.75 & 51,9 & 25,58 & 36,43 & 35,38 & 29,25 & 18,21 & 48,41 \\
\hline Number of points, $K=0,9$ & 1,8 & 2,25 & 4,05 & 3,15 & 3,15 & 3,6 & 4,5 & 2,7 \\
\hline $\begin{array}{l}\text { Wall construction period } \\
\text { with an area of } 87 \mathrm{~m}^{2} \text {, days }\end{array}$ & 11 & 9 & 4 & 6 & 6 & 5 & 3 & 8 \\
\hline Number of points, $K=1$ & 2 & 2,5 & 4,5 & 3,5 & 3,5 & 4 & 5 & 3 \\
\hline Fire resistance, min & $\begin{array}{c}\text { more } \\
\text { than } 300\end{array}$ & 15 & 45 & 45 & $\begin{array}{c}\text { not less } \\
\text { than } \\
120\end{array}$ & 60 & $90-150$ & $\begin{array}{l}\text { not less } \\
\text { than } 45\end{array}$ \\
\hline Number of points, $K=0,9$ & 4,5 & 0,9 & 1,8 & 1,8 & 3,6 & 2,7 & 3,6 & 1,8 \\
\hline Noise isolation, $\mathrm{dBA}$ & 60 & 36 & 40 & 33 & 60 & 44 & 42 & 60 \\
\hline Number of points, $K=0,7$ & 3,5 & 2,1 & 2,4 & 1,8 & 3,5 & 2,8 & 2,6 & 3,5 \\
\hline $\begin{array}{l}\text { Wall thickness without } \\
\text { insulation, } m\end{array}$ & 1,2 & 0,6 & 0,4 & 0,56 & 0,4 & 0,22 & $0,06-0,5$ & 0,15 \\
\hline Number of points, $K=0,4$ & 0,4 & 0,8 & 1,2 & 0,8 & 1,2 & 1,6 & 1,6 & 2 \\
\hline $\begin{array}{l}\text { Compression resistance, } \\
\mathrm{MPa}\end{array}$ & 30 & $37-45$ & $27-30$ & 22 & 27 & $18-22$ & 24 & 23 \\
\hline Number of points, $K=0,5$ & 2,0 & 2,5 & 1,8 & 0,8 & 1,5 & 0,5 & 1,3 & 1,1 \\
\hline $\begin{array}{l}\text { Material consumption, } \\
\text { m3. }\end{array}$ & 60,18 & 48,12 & 44,2 & 44,2 & 17,075 & 16,4 & 12,52 & 13,28 \\
\hline Number of points, $K=0,9$ & 0,9 & 1,8 & 2,25 & 2,25 & 2,7 & 3,15 & 4,5 & 3,6 \\
\hline Total points & 32,9 & 28,15 & 33,41 & 30,6 & 40,25 & $\mathbf{3 7 , 4 5}$ & 42,2 & 40,3 \\
\hline
\end{tabular}

Source: development by the authors according to sources [9-15].

It is also worth noting that the constructive and technological solution from a profiled bar is the most labor-consuming option, and has the least fire safety and strength.

Timber bricks and glued laminated timber have good heat conductivity and durability, but their construction time is longer than CLT or SIP buildings.

As can be seen from Table 1, the Light steel thin-walled structures solution is inferior to the CLT-panel wooden frame solution in terms of labor intensity, duration of work and material consumption. 
In addition, I would like to note a number of criteria that play an important role in selecting a constructive solution. The usage of a CLT-panel or SIP-panel, Light steel thin-walled structures thermal profile is justified by the low weight of metal structures and their good bearing capacity, easy processing, minimal values of foundation load, as well as processability and absence of necessity to lift equipment.

And the disadvantages of the CLT-panel can be solved by additional measures. For example, the effect of heat bridges can be reduced by using external insulation systems with vinyl siding, which was taken into account when designing this project. Increasing the fire resistance of a CLT panel is provided by one of the following ways: spraying and painting with various fire-resistant materials; Internal cladding with GKL sheets. The need for mandatory installation of a windbreak and a vapor barrier will ensure that the building is tight against wind, air and vapor migration through the structure, which significantly affects energy consumption, ventilation and indoor comfort.

Conclusions and offers. Due to the multi-criteria analysis method of structural and technological solutions in the main parameters, it was determined that a significant economic effect achieved by reducing the loads from the dead weight of structures, reducing transport and installation costs, reducing construction period without usage of heavy equipment, allows: firstly, to validate the design solution for the "Dubovaya Roshcha" mini-hotel construction, and secondly, further prospective development of this industry. The technology of wooden housing construction opens up the opportunities for solving issues related to the construction of comfortable, budgetary energyefficient buildings. Despite the fact that at the present the majority give preference to houses made of brick, aerated concrete or panels, world practice and factorial assessment of this study indicate that innovative technologies, which include CLT-panels, SIP-panels, Light steel thin-walled structures heat profile, bring undeniable benefits in the budget construction segment.

\section{References}

[1] Liubitseva O.O. Rynok turystychnykh posluh // www.tourlib.net. Statystyka / Derzhavnyi komitet statystyky Ukrainy // www.ukrstat.gov.ua.

[2] Эksport y ymport turystycheskykh usluh $\mathrm{v}$ Ukrayne// rezhym dostupa: https://zet.in.ua/statistika-2/turizm/eksport-i-import-turisticheskix-uslug-v-ukraine/

[3] Turyzm 2030. Hlobalnыi obzor / Tourism Towards 2030/ Global overview. URL: http://www.wise.co.th/wise/Knowledge_Bank/References/Tourism/UNWTO__ Tourism Toward_2030.pdf (data obrashchenyia: 24.04.2017)

[4] Stroytelnaia hazeta ;№ 41, okt., 1999 h, s. 8.

[5] Wei-Wen Yu La Boube Cold-Formed Steel Design. / Wei-Wen Yu, Roger A. //- 4th Edition yzd. - Hoboken, New Jersey: John Wiley \& Sons, Inc., 2010. - 528 p.

[6] Reshetnykov A.A. Sravnytelnыi analyz metodyk rascheta tonkostennыkh stalnыkh balok Sobraznoho profylia po otechestvennыm y zarubezhnыm normam/ A.A. Reshetnykov, V.Iu.Kornet, D.A. Leonova // Ynzhenernыi vestnyk Dona, 2018, №1.

[7] Dereviannoe domostroenye: tendentsyy, spros, predlozhenye / rezhym dostupa: http://www.accbud.ua/house/podgotovka-k-stroitelstvu/vazhno-znat/derevjannoedomostroenie--tendentsii--spros--predlozhenie

[8] N.V. Dmytryeva, A.N. Hostryk, Yvanova T.Y. O mnohokryteryalnom analyze tekhnolohycheskkh reshenyi hydroyzoliatsyy yzvestniaka-rakushechnyka Naukovyi zhurnal «Molodyi vchenyi» №7 (47) lypen, chastyna 1 «Vydavnychyi dim «Helvetyka». - m. Kherson, 2017.- S.20-25.

[9] Hryb L., Shadryn E. Yspolzovanye v Rossyy Norvezhskoho opыta mnohoэtazhnoho dereviannoho stroytelstva/ Seryia «Stroytelstvo»: sbornyk statei mahystrantov y aspyrantov. Vыpusk 3. V 2 tomakh. Tom 2 ; Sankt-Peterburhskyi hosudarstvennыi arkhytekturnostroytelnыi unyversytet. - Sankt-Peterburh, 2020.- S.29-41. 
[10] Sravnytelnыi analyz tekhnolohyi stroytelstva [Elektronnyi resurs] / N. Y.Vatyn, A. S. Synelnykov, A. V. Malosheva, D. V. Nemova - Rezhym dostupu do resursu: https://imekslstk.ru/services/privatePerson/stati/compare_technology.

[11] Bekrenëva T. A. Tekhnyko-эkonomycheskoe sravnenye varyantov vozvedenyia ohrazhdaiushchykh konstruktsyi sten mnohokvartyrnыkh zhylыkh zdanyi // StudArctic forum. Vыpusk 4 (4), 2016- S.8-13.

[12] Hrafyky zvukoyzoliatsyy konstruktsyy -Rezhym dostupu do resursu: https://remontpl.ru/zvukoizolyacziya/grafiki-zvukoizolyaczii-konstrukczii

[13] Sravnenye dereviannoho kyrpycha c brusom// rezhym dostupa: https://woodbrick.ru/technology/compare/

[14] Skrypka B.C., Sravnytelnыi analyz materyalov dlia dereviannoho domostroenyia/ Aktualnыe napravlenyia nauchnыkh yssledovanyi XXI veka, 2014, № 3, chast 2 (8-2) h. Ukhta- S.429433.

[15] K.V. Holubev, K.A. Fedotov Problemы yspolzovanyia novыkh tekhnolohyi maloэtazhnoho domostroenyia / K.V. Holubev, K.A. Fedotov //Vestnyk PNYPU. Urbanystyka, 2013. № 3 S.23-30.

\section{ПРО ВИБІР КОНСТРУКТИВНО-ТЕХНОЛОГІЧНОГО РІШЕННЯ БУДІВНИЦТВА МІНІ-ГОТЕЛЮ}

Дмитрісва Н.В., к.т. н., доцент, Одеська державна академія будівництва і архітектури dmitrieva.nv76@gmail.com, ORCID ID: 0000-0002-4828-1644

Агафонова І.П., старший викладач Бендерського філії ПГУ ім. Т.Г.Шевченка barkaririna@bk.ru,ORCID ID: 0000-0003-4330-2642

Туголуков Ю. С., магістрант Бендерського філії ПГУ ім. Т.Г.Шевченка zvezdastolicy@gmail.com ORCID ID: 0000-0002-3679-5955

\section{Анотація.}

У статті розглянуті особливості та переваги, інноваційних конструктивно-технологічних рішень в будівництві міні-готелів в рамках розвитку еко-туризму. Наведено дослідження основних потенціалів розвитку внутрішнього еко-туризму в Україні та Молдові, на прикладі м Тирасполя, Молдова. Розкриваються проблеми енерго- та ресурсозбереження. Охарактеризовані об'ємно-планувальні та конструктивні особливості проекту туристичного комплексу «Дубовий гай» в м Тирасполь, Молдова.

Обгрунтовано необхідність застосування методики багатокритеріального аналізу оцінки при оптимізації конструктивно-технологічних рішень зведення каркаса готельних будиночків Тип 1 і Тип 2 з урахуванням енергоефективності та використання екологічних матеріалів. Представлені результати оптимізації конструктивно-технологічних рішень. У дослідженні були виділені основні критерії, що впливають на вибір архітектурно-планувальних і конструктивно-технологічних рішень зведення каркаса: кількісні та якісні. До якісних критеріїв відносяться: можливість всесезонного монтажу; екологічність; пожежна безпека.

До кількісних критеріїв належать: вологість; мінімальна товщина стіни (без урахування утеплювача); шумоізоляція; трудомісткість та тривалість будівництва; довговічність; коефіцієнт теплопровідності. Представлено методику багатокритеріального аналізу конструктивно-технологічних рішень, заснованою на факторної оцінці варіантів вирішення зведення малоповерхових будівель. У дослідженні були виділені основні критерії та значимі коефіцієнти, що впливають на вибір будівельних конструкцій.

При відборі альтернатив i визначення оцінки критеріїв використовувався комунікативний індивідуальний метод - коли варіанти рішень генерує єдиний експерт. 
На підставі даних оцінки факторів, за 5-ти бальною шкалою, найбільшу кількість балів набрала технологія з CLT-панелі - 42,2 бала, найменше - оциліндрованої колоди -28,15 балів., це свідчить про те, що більшість показників показує найкращі дані рішення з CLT-панелей.

Запропоновано способи вирішення недоліків CLT-панелі, таких як утворення теплових мостиків можливо зменшити при використанні зовнішніх систем утеплення 3 обробкою вініловим сайдингом; забезпечення герметичності будівлі по відношенню до вітру, до повітря i до міграції пара через конструкцію - обов'язковим монтажем вітрозахисту i паронепроникного бар'єру покрівлі; підвищення межі вогнестійкості CLT-панелі, забезпечується одним із способів: напилення і забарвлення різними вогнетривкими матеріалами; внутрішнє облицювання листами ГКЛ.

Ключові слова: металеві конструкції, ЛСТК, дерев'яні конструкції, CLT-панелі, SIPпанелі, критерії оцінки, еко-будівництво.

\title{
О ВЫБОРЕ КОНСТРУКТИВНО-ТЕХНОЛОГИЧЕСКОГО РЕШЕНИЯ СТРОИТЕЛЬСТВА МИНИ-ОТЕЛЯ
}

\author{
Дмитриева Н.В., к.т.н., доцент, \\ Одесская государственная академия строительства и архитектуры \\ dmitrieva.nv76@gmail.com ORCID ID:0000-0002-4828-1644 \\ Агафонова И.П., старший преподаватель, \\ Бендерский филиал ПГУ им. Т.Г.Шевченко \\ barkaririna@bk.ru ORCID ID: 0000-0003-4330-2642 \\ Туголуков Ю. С., магистрант \\ Бендерский филиал ПГУ им. Т.Г.Шевченко \\ zvezdastolicy@gmail.com ORCID ID: 0000-0002-3679-5955
}

\begin{abstract}
Аннотация. В статье рассмотрены особенности и преимущества, инновационных конструктивно-технологических решений в строительстве мини-отелей в рамках развития эко-туризма. Приведены исследования основных потенциалов развития внутреннего экотуризма в Украине и Молдове, на примере г. Тирасполь, Молдова. Раскрываются проблемы энерго- и ресурсосбережения. Охарактеризованы объемно-планировочные и конструктивные особенности проекта туристического комплекса «Дубовая роща» в г. Тирасполь, Молдова.

Обоснована необходимость применения методики многокритериального анализа оценки при оптимизации конструктивно-технологических решений возведения каркаса гостиничных домиков Тип 1 и Тип 2 с учетом энергоэффективности и использования экологических материалов. Представлена методика многокритериального анализа конструктивнотехнологических решений, основаная на факторной оценке вариантов решения возведения малоэтажных зданий. При отборе альтернатив и определение оценки критериев использовался коммуникативный индивидуальный метод - когда варианты решений генерирует единственный эксперт.

На основании данных оценки факторов, в 5-ти бальной шкале, наибольшее количество баллов набрала технология с CLT-панели - 42,2 балла, меньше - оцилиндрованное бревно 28,15 баллов. Это свидетельствует о том, что большинство показателей показывает лучшие данные решения по CLT-панелей.

Ключевые слова: металлические конструкции, ЛСТК, деревянные конструкции, CLTпанели, SIP-панели, критерии оценки, эко-строительство
\end{abstract}

